\title{
UNEXPLORED ASPECTS OF SOUTH AFRICA'S FIRST WORID WAR HISTORY
}

\begin{abstract}
Although the Great War of 1914-18 is within living memory it is disturbing to discover how many gaps there seem to be in our knowledge of this subject. In this offering I shall consider some of these in the hope that the interest of other researchers may be aroused, before the last of the veterans of that most terrible of all wars, fade away.
\end{abstract}

I wonder how many people who are interested in our military history have read Jan van Melle's short stories?' ${ }^{1}$ Two of these, Die Joiner and Weer by die huis, are to my mind quite outstanding. Jan van Melle rode with the rebels, but in these two stories he has left us with a wonderfully vivid and objective insight into this tragic time. His 'joiner' (a republican who had fought for the British during the South African War of 1899-1902) had cared nothing for the issues of the Three Years War. A youth at the time, he had been misled by his father for whom the attractive pay offered by the British Forces was the most important consideration. Long afterwards he realised what he had done and sought propitiation for his sins by serving under Commandant Jopie Fourie until the bitter end of the Rebellion. How often do we not overlook this important truth? The reasons why men serve in wars are not always the obvious ones.

Dolf van Niekerk's historical novel Die son struikel $^{2}$ is useful to the student of military history because it reminds us vividly that in many cases the same people bore the brunt of the suffering in 1899-1902, 1914-15 and 1922. The medals of those who served in the burgher commandos of 1914-15 are seldom encountered. The reasons for this are not hard to find. Van Melle shows us that like his South African War 'Joiner' many of the conscript burghers of 1914-15 only became aware of the issues of the Rebellion as time wore on. Unquestionably a number of those who put down the Rebellion were later filled with remorse at what they had done and when the badges of collaboration, in the form of medals, arrived after the war, many of them were probably thrown away. Arthur Barlow has recorded that many of the miners who vere veterans of the Great War were so disgusted with the Government's handling of the Rand Revolution that they returned their medals to the British War Office. ${ }^{3}$

The importance of the role of Blacks and Coloureds in the conquest of German South West Africa has received scant attention. 33556 Blacks served as labourers in the Union Defence Forces between 4 August 1914 and 31 August 1915. (All save 1326 from Bechuanaland and 58 from Basutoland were South Africans). But these figures are incomplete because they do not include those who 'were engaged independently and taken to South West Africa by units or individuals.'t Nor do they include the Native Artillery Drivers in the South African Field Artillery and other gunner units. ${ }^{5}$ (C/Cpl E. Mokosi, who later served in the South African Police, and was awarded the 1914-1915 Star, British War Medal 1914-1920 and Allied Victory Medal was one of these men. He served with the South African Mounted Riflemen - Field Artillery Battery between 10 March and 9 July 1915).

The work of the Herero scouts in the Union Defence Forces is mentioned by Captain (later Lieutenant Colonel) C. M. Murray of the South African Medical Corps in his diary which has been published in the periodical Chronicle of the Family, which also contains much other useful information. Dr Murray gives the strength of their Intelligence Section as 'about 30 Herero natives' and records that they were commanded by Captain Kennedy and Lieutenant Howie. ${ }^{6}$ (The present writer questioned Major the Hon P. V. G. van der Byl who was on General Botha's Staff about the Herero Scouts, but he was unable to shed any light on the matter).

The work of the Bondelswarts in the campaign is another neglected field. Abraham Morris, who led his people into rebellion against the Union Government in 1922, served as a guide in the Union Defence Forces.? He was in the Steinkopf Unit of Intelligence of the South African Mounted Riflemen between 27 August 1914 and 7 May 1915.

The Indian Stretcher Bearer Corps was raised 


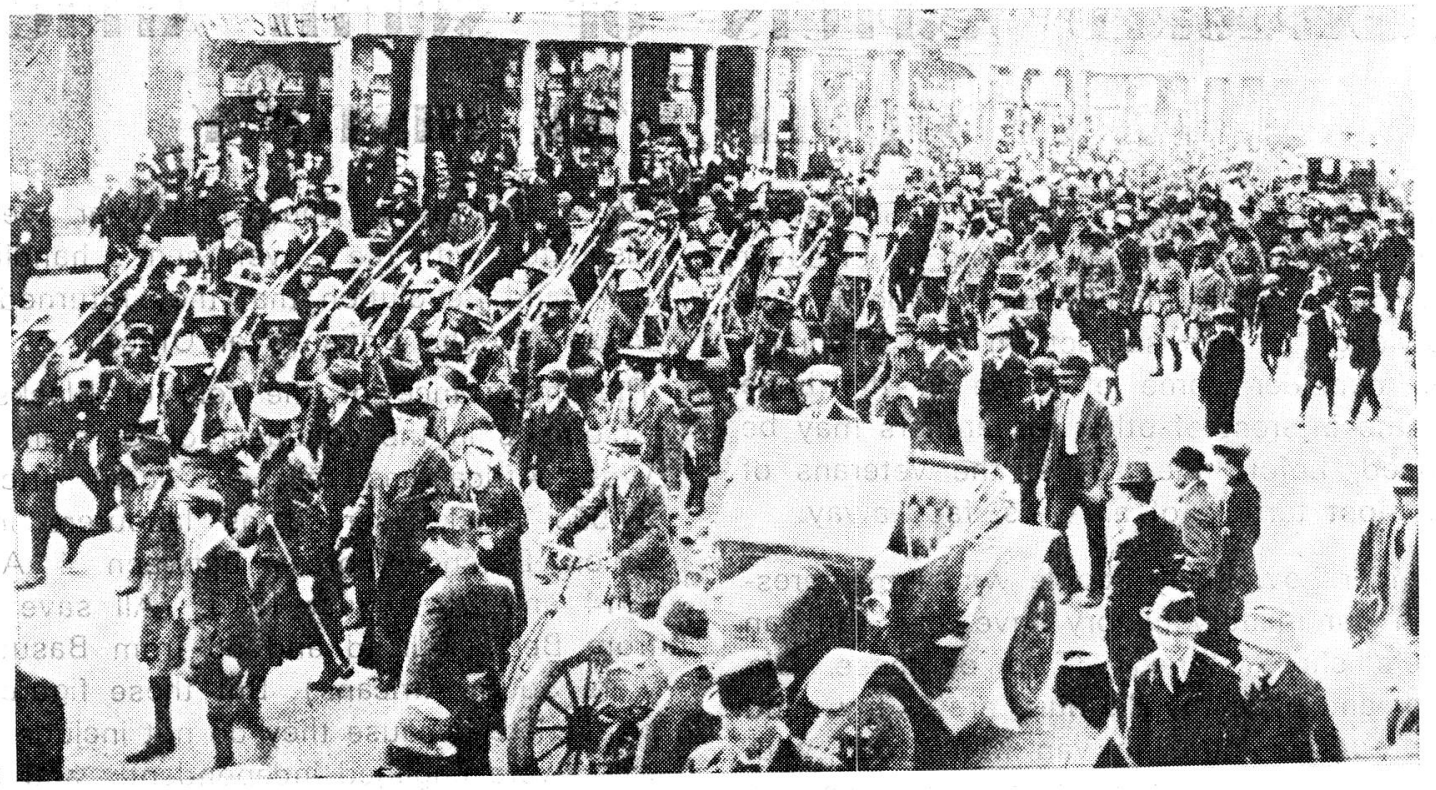

Contingen $\hat{e}_{\text {of }}$ Union forces marching through Cape Town after the successful conclusion of the South West Africa Campaign. Non-European drivers can be seen at the rear of the column.

by Gandhi for service in the South African War of 1899-1902 and was employed again in the Natal Rebellion of 1906. I have seen a 1914-15 Star officially named to 'PTE A. B. CHEGANY, INDIAN BR CORPS's and from this the general reader would conclude that the unit saw service in the German South West Africa Campaign, although Professor Pachai mentions only that the 1st and 2 nd Indian Bearer Companies served in German East Africa. However, Union Defence Forces records show that the 1914-15 Star was awarded for service at any time during those two years, and also for service in theatres of war other than German South West Africa. This is clear from details of the war service of A. B. Chengany.* Pte L. J. Singh of the 1st Indian Bearer Company was awarded the Indian Distinguished Service Medal.

The role of Coloured personnel in the German South West African Campaign has never received the attention it deserves. Although Captain Ivor Difford devoted only a few lines of his monumental work, The Story of the 1st Battalion Cape Corps 1915-1919, to this topic, what he recorded is of the highest significance. In the foreword to the book he wrote, 'a large number of Coloured men participated in the German South West African Campaign as Artillery and Transport drivers, motor drivers and mechanics, as Officers' servants and in various other noncombatant capacities, and performed much useful work'. At this point in time it would be quite wrong to suppose that it is too late to research this topic fully. Some of the veterans survive and there is the highly important record of the Union Defence Forces Medal Roll for the 1914-1918 War. We know that Coloured Artillery Driver Michael van der Poel served with the Field Artillery Battery SAMR in the German South West Africa Campaign and was awarded a 1914-15 Star. (On 26 October 1915 he enlisted in the 1st Cape Corps). ${ }^{11}$ In his introduction to Captain Difford's book Mr Merriman explains that it was the good services of Coloureds in the German South West African Campaign which prompted the Prime Minister to raise the $1 \mathrm{st}$ Cape Corps for combatant service in German East Africa. ${ }^{12}$

The Cape Corps was not resuscitated until September 1915. For a number of Coloured men the inactivity prior to this date was more than they could bear, so they packed their bags and sailed for England, where they joined the British Army. (It is not known

\footnotetext{
* ANTHONY BASTIAN ChENGANY. Enlisted in 1 Indian Bearer Company 15 October 1915. No previous military experience. Embarked in HMS Trent at Durban on 16 December 1915, arrived in East Africa on 22 December 1915. Served in German East Africa until 18 December 1916, subsequently discharged as medically unfit for military service. Awarded 1914-15 Star. British War Medal, Victory Medal. The main South African force only left Durban on 24 December 1915, thus arriving too late to qualify for the 1914-15 Star.
} 
whether a record of their services has been compiled).

The work of the many South Africans who served in the British Forces during the war provides a fascinating study. Although the prowess of our early flyers is well known, few are aware that a former Natal Field Artillery subaltern, Second Lieutenant Norman C. Spratt, who had been commissioned in the Royal Flying Corps Special Reserve on 5 August 1914, fought what was probably the first recorded aerial battle involving two aircraft. Some of Lieutenant Spratt's exploits are described by Lieutenant Colonel L. A. Strange in his book Recollections of an Airman. ${ }^{13}$ Most of the boys who had served in the Mafeking Cadet Corps during the siege served in the British or South African Forces during the Great War. Luke L. Green, who had held a comission in the unit, joined up in 1915 and was posted to the Rifle Brigade in which he served in France. He was wounded and decorated with the Military Cross. In 1919 he took part in the operations in North Russia where he was awarded the Distinguished Service Order and mentioned in despatches. E. E. Wright, another Mafeking cadet, who was 9 years old when he joined the corps, served overseas in the Royal Sussex Regiment during the Great War and was later commissione din the Royal Flying Corps.

25090 Blacks from South Africa, Basutoland, Bechuanaland, and Swaziland made a valuable contribution to the war effort on the Western Front, which earned them an appreciative message from Field Marshal Lord Haig and the Secretary of State for the Colonies at the conclusion of the campaign. ${ }^{14}$ In $1973 \mathrm{Mr}$ James Nkomo, a Rhodesian who had served in the 25th Company of the South African Labour Battalion in France as a linesman and ammunition supply hand recalled that his happiest moments of the war had been short spells of leave which he had spent in England visiting cathedrals, churches and other tourist attractions with the Reverend $\mathrm{H}$. O Bragg with whom he was staying. ${ }^{15} \mathrm{Mr}$ Schreiner, the Union's High Com-

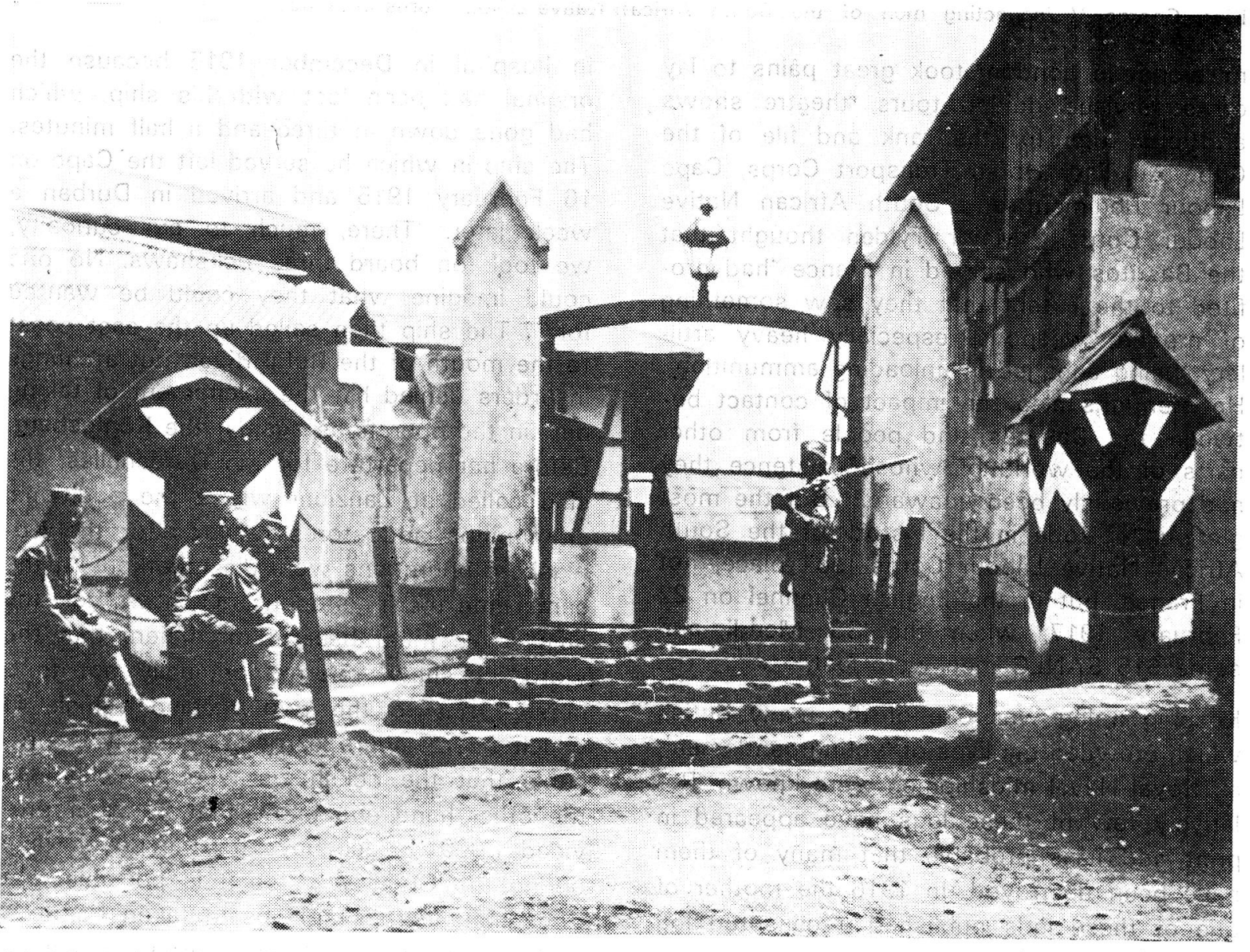

German African troops or 'askaris' standing guard at a fort in German East Africa. World War II. 


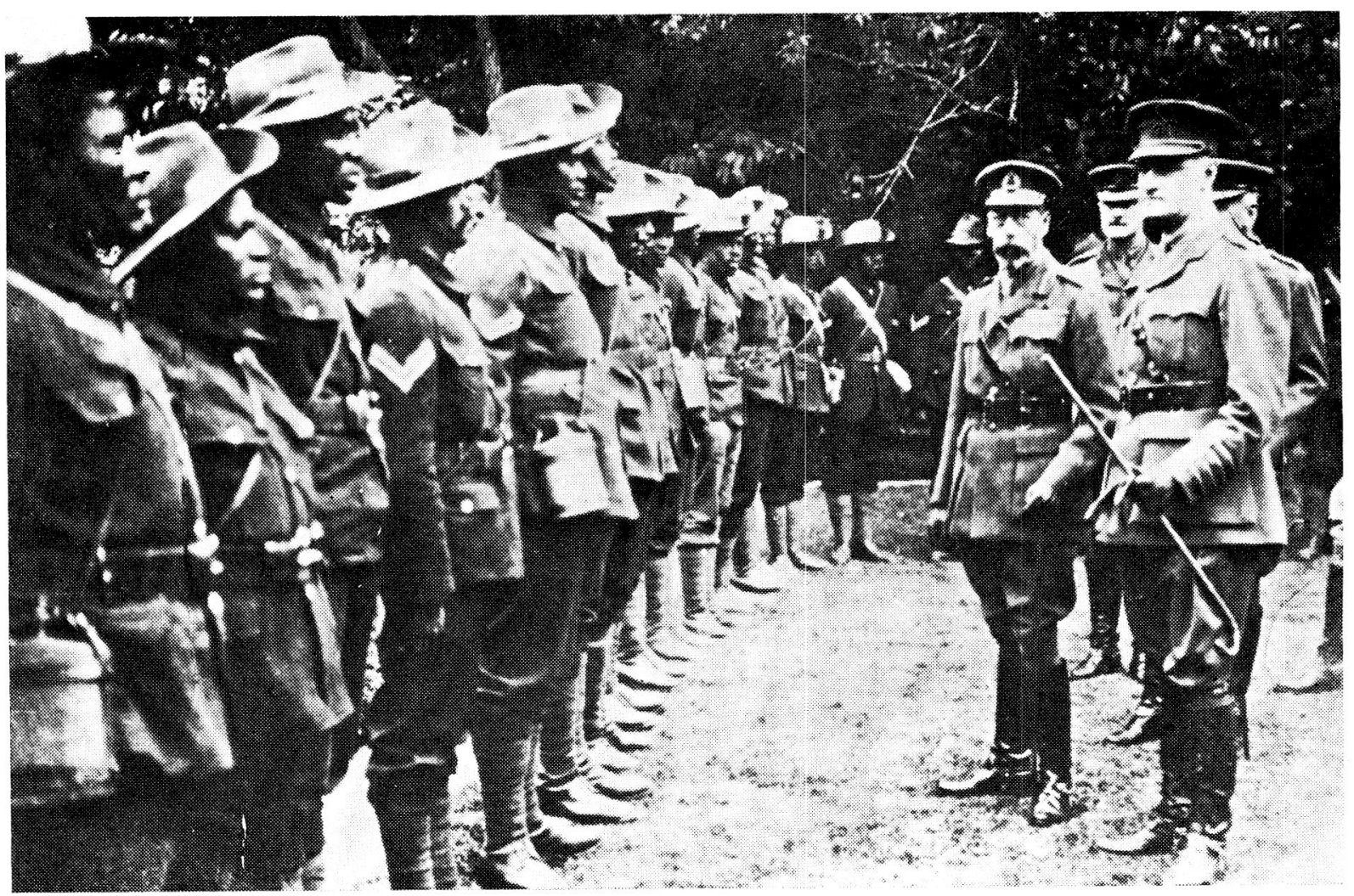

King George $V$ inspecting men of the South African Native Labour Corps in France.

missioner in London, took great pains to lay on supervised guided tours, theatre shows and bus trips for the rank and file of the Cape Auxiliary Horse Transport Corps, Cape Labour Regiment and South African Native Labour Corps. ${ }^{16}$ Major Tylden thought that the Basutos who served in France 'had profited to the extent that they saw something of modern weapons, especially heavy artillery, being engaged in unloading ammunition'. $\mathrm{He}$ mentions also the impact of contact between the Basutos and people from other parts of the world of whose existence they had previously been unaware. ${ }^{17}$ But the most glorious episode in the history of the South African Native Labour Corps took place, not in France, but in the English Channel on 22 February 1917, when the SS Mendi and some 615 SANLC men were lost. ${ }^{18}$

Keeping a log was one of the many duties which crowded the lives of 'young gentlemen', as Royal Naval midshipmen were known. Relatively few of these logs have appeared in print and it is probable that many of them have been destroyed. In 1916 the mother of one of these lads published a censored log which her son had rewritten from memory in hospital in December 1915 because the original had been lost with his ship, which had gone down in three and a half minutes. The ship in which he served left the Cape on 16 Feloruary 1915 and arrived in Durban a week later. 'There, much to our curiosity, we took on board three rickshaws. No one could imagine what they could be wanted for.' ${ }^{19}$ The ship then sailed up the east coast to the mouth of the Rufiji River, but a change in orders denied her the excitement of taking part in the operations against the Königsberg. Before her departure for the Dardanelles, the ship called at Zanzibar where the additional ammunition and stores required for the Königsberg operations were disembarked. At the same time the 'mysterious rickshaws' left the ship. ${ }^{20}$ We must bear in mind here that the word 'rickshaw' referred originally not to a person, but to the two-wheeled vehicle in which people were carried. Hence it is probable that the rickshaws were vehicles. On the other hand, we know that Zanzibar provided 1000 Seedee boys for the Royal Navy during the Great War, so it is possible that three men were simply being taken home. If there were indeed three Durban rickshaw 
drivers, it would be intriguing to know what their mission was.

The letters from the front written by Captain A. J. Molloy, MC of the 5th South African Infantry give a valuable picture of the war and remind us just how little censorship there was. Captain Molloy, who was thrice decorated and twice mentioned in despatches for his part in the German East African Campaign, was the last of a line of British officers with impressive records of service. Unlike his forebears, he had served for many years as a ranker first in the British Army in India and then in the Cape Mounted Riflemen and the South African Mounted Riflemen here, before being commissioned for the second time in German East Africa. On 7 April 1916 he sent his friend Middleton the following summary of the 'points which has struck him most forcibly':

1. That we have a lot to learn in the way of bush fighting from our black enemies, and that in spite of all talk to the contrary, we have found them an enemy to be fully reckoned with. He is resourceful, brave and well

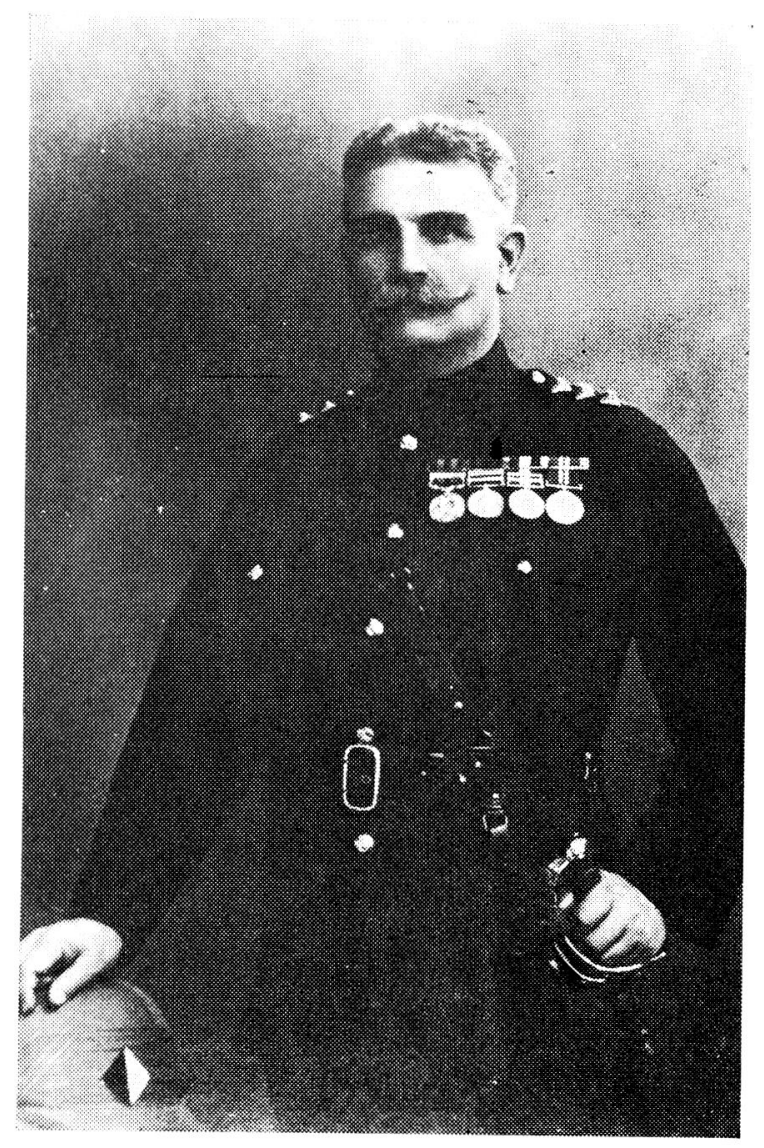

Capi A. J. Molloy 5 SA Infantry Battalion in 1917. trained for this kind of fighting. I have heard he is a bad shot, but the casualties in action prove the opposite. He is however a brute and does not hesitate to mutilate and kill all wounded or prisoners. I don't think the Germans put much restraint on this peculiarity. They would be nowhere without him, the "Askari" as he is called.

2. That the Germans can teach us something in the art of concealment and defence. 3. That this campaign has been an eye opener to our G.S.W. warriors. They have seen more here in one day than occurred in the whole G.S.W. campaign.

4. That India can produce soldiers worthy of that name, who have maintained the best traditions of the British Army in German East Africa.

5. The King's African Rifles, a native regiment, have proved themselves to be excellent soldiers, and deserve every praise.

6. That with trained troops, we would not have suffered one half of the casualties we did. The heaviest casualty list is by no means a proof that that particular regiment bore the brunt of the fight. In my opinion, it generally denoted the untrained soldier, not well handled. I can honestly say we have nothing to learn from any of the other S.A. Regiments in the way of being efficiently handled. We are far from perfect ourselves.

7. A deficiency of maxim guns and how to use them.'21

The work of the many volunteer units which served on the home front during the Great War could probably be pieced together with the aid of newspaper reports, though the picture would be somewhat incomplete. Most of those who served in these units were over military age or unfit for full-time service and have been dead for many years, but it should be borne in mind that units like the Cape Peninsula Garrison Regiment also catered for men who were under age. This group, which may now be very small and the then teenage members of their families will surely have vivid memories of the part-time parades which interrupted their leisure time programme and it is this source of information which researchers should tap. It is greatly to be hoped that where post-graduate students are engaged in writing the history of a city or 


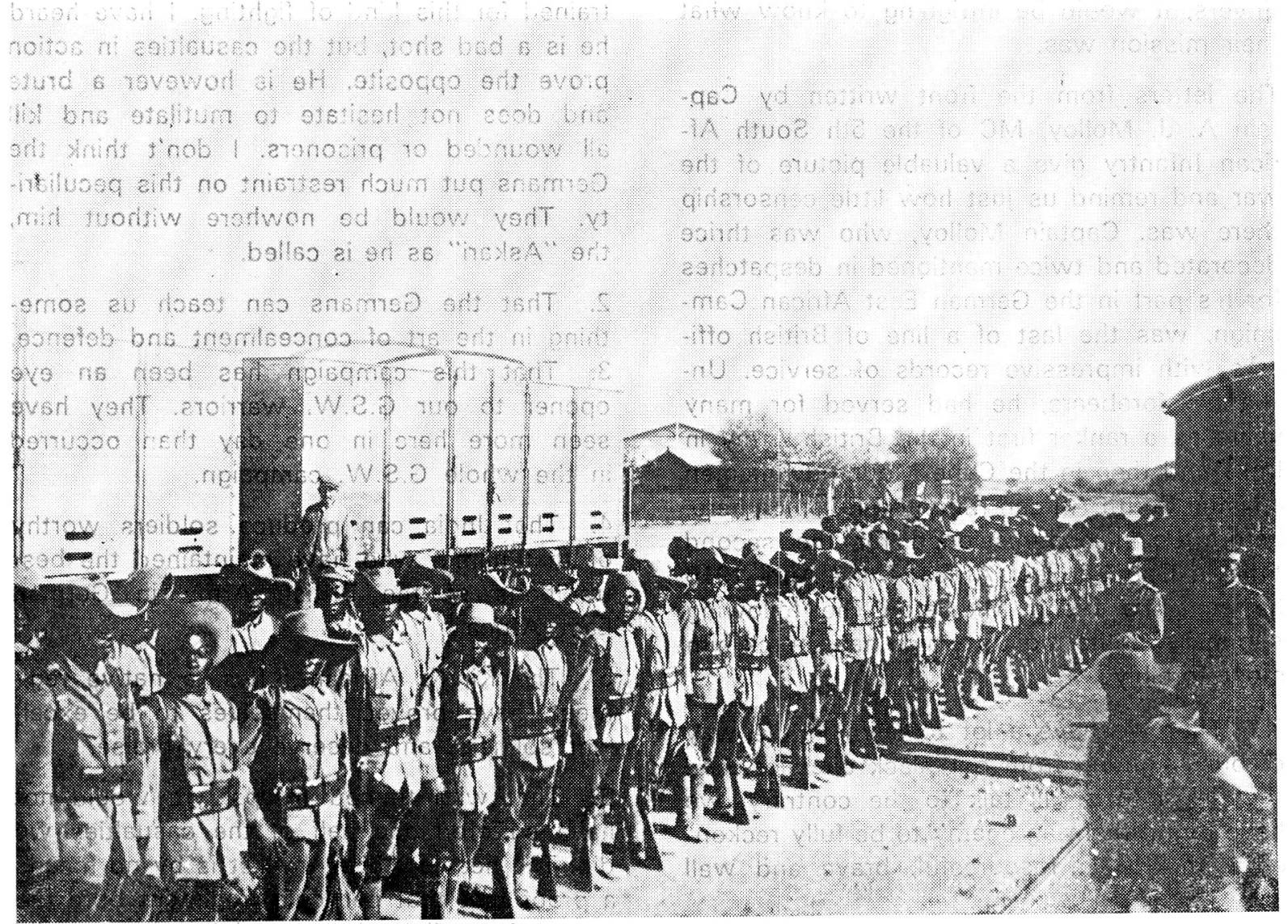

German South West Africa: German Native Corps officered by Europeans.

town they will give some attention to the units which only flourished in wartime. Commandos or Defence Rifle Associations did valuable service in the Great War both in the fjeld and at home. Our modern commandos are their direct descendants and can be proud of their ancestry. Whilst it is understandable that Cape Town should have its own Defence Rifle Association, it will probably come as a surprise to inhabitants of Claremont, Rondebosch and Wynberg/Constantia to know that each of these suburbs also had one.

Much valuable information has already appeared in print - the secret is to know where to find it. British Jewry Book of Honour 19141918 published by Caxton contains a nominal roll of all the members of South African Jewry who served in the Union Defence Forces, including the 'old and bold' units like the Cape Peninsula Garrison Regiment. The Member of the Legislative Assembly for Cape Town (Castle), Advocate Morris Alexander, K.C., served as a Private in the Regiment. The Rolls of Honour/War Records and Books of Remembrance of Universities, Colleges and
Schools published here and in the United Kingdom contain much useful information about the war services of South Africans.

Details of the South Africans who were decorated during the war may be found in The Union of South Africa Year Book 1918, Department of Census \& Statistics, Pretoria, pages 36:3-373. This does not include Mentions in Despatches some of which are to be found in the following supplements to the London Gazette:

German South West African Campaign: Number 30856 dated 22nd August 1918. German East Africa:

: Number 29933 dated 8th February 1917. : Number 30560 dated 7th March 1918

: Number 31156 dated 31st January 1919. : Number 31387 dated 5th June 1919.

The British monthly Army List contains a useful roll of South African Officers and Warrant Officers with the usual additional information - previous war service, honours and date of promotion. It is thought that only those who 
served overseas are listed. Although the roll contains spelling errors and the 1919 roll lists officers who had been killed in the War, it is a valuable aid because it reminds us of the existence of units such as the Indian Labour Corps which is not mentioned by Major Tylden or Professor Pachai. The only officer in the unit was Captain T. E. W. R. Wood who is recorded as having been commissioned as a Temporary Second Lieutenant in the 3rd Battalion of the Dorset Regiment on 16 March 1917.

At this time, when Coloureds, Indians and Blacks are again playing an important part in the defence of South Africa, they should be reminded of the wonderful record of their forbears.

\section{NOTES:}

1. Uys Krige, Keur uit die Verhale van Jan van Melle.

2. Do!f van Niekerk, Die Son Struikel. Johannesburg, 1969.

3. Arthur Barlow, Almost in Confidence. Cape Town, 1952. P 179.

4. Union of South Africa Year Book, 1918. P 378

5. F. B. Adler, A. E. Lorch, and H. H. Curson, The
South African Field Artillery in German East Africa and Palestine 1915-1919. Pretoria, 1958. P 7.

6. Capiain $\operatorname{Dr}$ C. M. Murray in Chronicle of the Family, Vol 3, No 2, August, 1915, edited by C. K. Murray, privately printed. P 37.

7. Richard Freislich. The Last Tribal War - A Histrry of the Bondelswart Uprising in South West Affica 1922. Cape Town, 1964. P 9.

8. War Medal Collection of Dr F.'K. Mitchell, JCD, FSANS.

9. Proiessor B. Pachai, The International Aspects of the South African Indian Question 1860-1971. Cape Town, 1971. P 74.

10. Captain Ivor Difford, The Story of 1st Battalion Cape Corps 1915-1916. 1920.

11. Hbid, n 350 .

12. Ibid, introduction).

13. Lieutenant Co'onel L. A. Strange, Reco'llactions of an Airman. London, 1933. Pp 48-49.

14. The Union of South Africa and the Great War 1914-18 - Official History. Pretoria, 1924. P 219.

15. The Wanderer's Column, The Argus, 22 Nov 1973 , p 52.

16. E. A. Walker, W. P. Schreiner - A South Aírican. Oxford, 1937. P 373.

17. Major G. Tylcien, The Rise of the Basuto. Cape Town, 1950. P 217.

18. Ons Nie-Blankes het 'n trotse naam. In 'Bylae tot Die Burger', 14 June 1962. P 7.

19. His Mother (ed), From Dartmouth to Dardanelles, - A Midshipman's Log. London, 1916. P. 132.

20. Ibid. $p 138$.

21. Letier from Captain (later Major) A. J. Molloy, MC to Middleton dated 7 April 1916. (Military Museum, The Castle, Cape Town). 